\title{
Foraging, oviposition sites and notes on the natural history of the harvestman Heteromitobates discolor (Opiliones, Gonyleptidae)
}

\author{
Norton Felipe dos Santos Silva ${ }^{1,2}$ \& Rodrigo Hirata Willemart ${ }^{1,2,3,4}$ \\ ${ }^{1}$ Universidade de São Paulo, Escola de Artes, Ciências e Humanidades, São Paulo, SP, Brazil. \\ ${ }^{2}$ Universidade Federal de São Paulo, Programa de Pós Graduação em Ecologia e Evolução, São Paulo, SP, Brazil. \\ ${ }^{3}$ Universidade de São Paulo, Instituto de Biociências, Programa de Pós Graduação em Zoologia, \\ São Paulo, SP, Brazil. \\ ${ }^{4}$ Corresponding author: Rodrigo Hirata Willemart, e-mail: willemart@usp.br
}

SILVA, N.F.S., WILLEMART, R.H. Foraging, oviposition sites and notes on the natural history of the harvestman Heteromitobates discolor (Opiliones, Gonyleptidae). Biota Neotropica. 15(3): e20140186. http://dx.doi.org/10.1590/1676-06032015018614

\begin{abstract}
The lack of data on the natural history often hampers phylogenetic studies on the evolution of behavior. Herein we provide quantitative field data on foraging and oviposition sites of a Neotropical harvestman belonging to a subfamily with a published phylogeny, Goniosomatinae. Heteromitobates discolor rests during the day on granitic boulders on rivers, laying eggs in sheltered and darker areas. The female guard the eggs and aggressively respond to approaching conspecific females. In the absence of the female, ants, conspecifics and reduviids may predate the eggs. Egg-guarding females are known not to leave the clutch, but males and non-guarding females may leave the granitic boulders and forage on the vegetation at night, close to the river margins and with no difference in the sites explored between males and females. The general features described in $H$. discolor are similar to what has been reported for other species in this subfamily, suggesting an evolutionary conservatism within the group.
\end{abstract}

Keywords: Parental care, maternal care, microhabitat choice, substrate choice, Laniatores, Goniosomatinae.

SILVA, N.F.S., WILLEMART, R.H. Forrageamento, sítios de oviposição e notas sobre a história natural do opilião Heteromitobates discolor (Opiliones, Gonyleptidae). Biota Neotropica. 15(3): e20140186. http://dx.doi.org/10.1590/1676-06032015018614

Resumo: A falta de dados de história natural por vezes dificulta estudos filogenéticos sobre a evolução do comportamento. Nesse estudo nós fornecemos dados quantitativos de campo sobre forrageamento e sítios de oviposição de um opilião Neotropical pertencente a uma subfamília com uma filogenia publicada, Goniosomatinae. Heteromitobates discolor passa o dia em rochedos graníticos em rios, onde deposita os ovos em áreas abrigadas e escuras. A fềmea cuida dos ovos e responde agressivamente a fêmeas co-específicas que se aproximam. $\mathrm{Na}$ ausência de fềmeas, formigas, co-específicos e percevejos reduvídeos podem predar os ovos. Fêmeas que guardam ovos não deixam as desovas, mas machos e fêmeas sem ovos deixam os rochedos graníticos e forrageiam sobre a vegetação à noite, próximos à margem do rio e sem diferença nos sítios explorados entre os machos e as fềmeas. As características gerais descritas em $H$. discolor são similares ao que tem sido reportado para outras espécies nesta subfamília, sugerindo um conservadorismo evolutivo dentro do grupo.

Palavras-chave: Cuidado parental, cuidado maternal, escolha de micro-habitat, escolha de substrato, Laniatores, Goniosomatinae.

\section{Introduction}

Harvestmen are often nocturnal animals that shelter during the day under rocks or tree trunks, on leaf litter, on trees, shrubs and in caves. Their foraging site is often different, and distinct species may descend from the vegetation to forage on leaf litter, or leave caves or the underside of rocks to forage on the vegetation. The different types of substrates used when foraging have recently been used as characters for phylogenies, but data are scarce due to the low number of studies (Curtis \& Machado 2007; Caetano \& Machado 2013). Harvestmen feed on a number of items, including small invertebrates, dead animals, plant material and even fungi (Acosta \& Machado 2007).
The oviposition site may also be slightly different from the foraging and resting areas because most harvestmen species search for humid and protected sites to lay eggs (Curtis \& Machado 2007; Machado \& Macías-Ordóñez 2007). In the subfamily Goniosomatinae (Laniatores, Gonyleptidae), females of all the species studied take care of the eggs and of first instar immature (Machado 2002; Machado \& MacíasOrdóñez 2007), and males of at least some species patrol the females with which they have copulated. Males may also take care of the eggs if females are experimentally removed from the batch (Machado \& Oliveira 1998; Buzatto \& Machado 2009).

Although Goniosomatinae is the laniatorid group of species with most published behavioral studies, only four of the 36 species 
(DaSilva \& Gnaspini 2009) have been studied behaviorally in detail (e.g. Serracutisoma spelaeum (Mello-Leitão 1933); Heteromitobates albiscriptus (Mello-Leitão 1932); Acutisoma longipes (Roewer 1913); Serracutisoma proximum (Mello-Leitão 1922) - Gnaspini 1996; Machado \& Oliveira 1998; Willemart \& Gnaspini 2004a; Buzatto et al. 2011). Because there is a published phylogeny of the subfamily (DaSilva \& Gnaspini 2009), this group is excellent to study the evolution of behavior when using data from several papers. However studies on the natural history of more species are necessary because we often generalize data obtained for a few species for the entire subfamily, which is not necessarily accurate.

Herein we provide field data about foraging and oviposition sites of the Neotropical harvestman Heteromitobates discolor Soerensen 1884 (Gonyleptidae, Goniosomatinae), asking what are the exact sites that this species use for both these activities.

\section{Material and Methods}

We conducted this study in an Atlantic rainforest in the city of Ubatuba $\left(723,883 \mathrm{Km}^{2}\right)$, State of São Paulo, Southeast of Brazil. We used four rivers: Marimbondo ( $\mathrm{Km} 75)$, and Cachoeira da Bacia (Km 69), both close to Rodovia SP-55; Camburi (Km 1) and Corisco (Km 11), both close to Rodovia SP-101, the latter two belonging to the Parque Estadual Serra do Mar. Data on foraging were collected in April 2014, which is the end of the warm and rainy season, in three different populations by the rivers Marimbondo, Camburi and Corisco. We used two transects per river, both parallel to the river, $25 \mathrm{~m}$ long, $4 \mathrm{~m}$ wide and $4 \mathrm{~m}$ high, one in the right margin and the other in the left margin of each river (Fig. 1). Because the animals are large $(\sim 10-15 \mathrm{~cm}$ leg spam), they could easily be seen up to four meters high. The rivers typically have an area with no trees at their margins $(\sim 1.5 \mathrm{~m}$ from the river margin towards the forest). Beginning from where the vegetation starts, we counted $2 \mathrm{~m}$ perpendicularly away from the river throughout the $25 \mathrm{~m}$ of the transect, and this was called Zone 1. Zone 2 was parallel to Zone 1 but from $2 \mathrm{~m}$ to $4 \mathrm{~m}$ away the region where vegetation starts (Fig. 1). Two researchers monitored each $1 \mathrm{~m}^{2}$ of the transect for two minutes in each of the zones. Because studies with other Gonosomatinae species are known to forage on vegetation (e.g. Santos \& Gnaspini 2002), we did not search for animals on boulders on the river. Because this species was known to be nocturnal based on preliminary observations by the authors, we have collected data from $21 \mathrm{~h}$ to $3 \mathrm{~h}$ AM during one night. For every animal found, we measured the distance in a straight line of the animal to the forest floor and the distance in a straight line to the river margin. We also took note of the type of substrate (rocks or vegetation) and the posture of each individual.

For oviposition sites, we studied three populations by the margins of the rivers Marimbondo, Cachoeira da Bacia and Camburi. We defined a $100 \mathrm{~m}$ transect by the margins of each river. We looked for females and their egg batches in open and exposed areas of large boulders on rivers (Figs. 2A, B). The rivers width varied between $3 \mathrm{~m}$ to $15 \mathrm{~m}$. For every animal found, we measured the distance of the animal to the river and the distance of the female to the margin of the egg batch. We also measured the distance of nearby females and of males within $1 \mathrm{~m}$ to the focal egg batch. Males in this subfamily typically have distinguishable two morphs, which we will call major (larger) and minor (smaller) males (Buzatto \& Machado 2014). These were considered separately for data related to reproduction (oviposition sites) but not for foraging, since, for other species in the subfamily, there is evidence for distinct behaviors in the former (Buzatto et al. 2011, 2014) but not in the latter context. We classified the clutches to be either on exposed (walls directly exposed to sunlight) or non-exposed rocks (see Chelini et al. 2012). Clutches found on rocks were separated in either naked rock or rock with vegetation. A luximeter application for Android was used to classify the luminance in one of these seven categories: 5, 22, 75, 220, 800, 2800 and 6000 lux, with the probe $2 \mathrm{~cm}$ over from the eggs and always between 11AM-13h. We also registered the presence of fungi infecting eggs. We made all these observations on oviposition sites in May 2013, which is the transition to the cold and drier season. We took pictures of the eggbatches to count the number of eggs. These pictures were taken from March to June 2013 and from January to April 2014. We made the opportunistic observations described herein between March and July 2013 and in March 2014.

\section{Results}

\section{Foraging}

We found 24 males and 17 females foraging in Zone $1(0-2 \mathrm{~m})$, five males and two females foraging in Zone 2 (2-4 m). Pooling

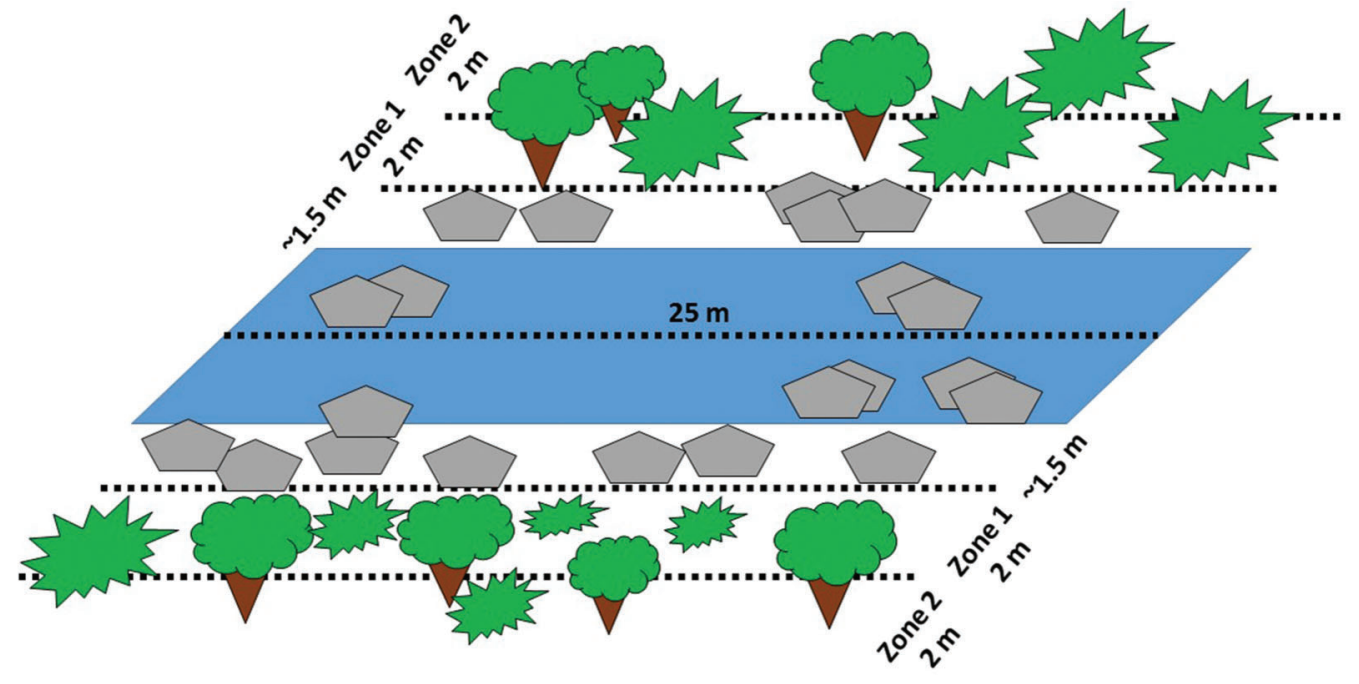

Figure 1. The transect used for studying foraging in the harvestman Heteromitobates discolor (not to scale), showing the river (blue), boulders (grey) and the vegetation (green). See text for further explanation. 
data from the two Zones, males were $123 \mathrm{~cm}$ (mean; $\mathrm{SD}=82.62$; $\min =20 ; \max =310 \mathrm{~cm} ; \mathrm{n}=29$ ) and females $80 \mathrm{~cm}$ (mean; $\mathrm{SD}=81.83 ; \min =45 ; \max =300 \mathrm{~cm} ; \mathrm{n}=19$ ) from the floor. Males were $255 \mathrm{~cm}$ (mean; $\mathrm{SD}=147.83 ; \min =100 ; \max =610$ $\mathrm{cm} ; \mathrm{n}=29)$ from the river water and females were $300 \mathrm{~cm}$ (mean; $\mathrm{SD}=69.0 ; \min =100 ; \max =350 \mathrm{~cm} ; \mathrm{n}=19$ ). Males and females did not differ in the distance to the river or to the forest floor, both considering the two zones separately or with data from the two zones pooled (data pooled, distance to river: Mann-Whitney test, $\mathrm{U}=479.5 ; \mathrm{n}=19$ females, 29 males; $\mathrm{p}=0.779$; data pooled, distance to floor: $\mathrm{U}=421 ; \mathrm{n}=19$ females, 29 males; $\mathrm{p}=0.354)$.

In Zone 1, nine of the 24 males were on rocks and 15 on vegetation, the latter including leaves, bromeliads, plant stems and tree trunks. Among females, four were on rocks and 13 on vegetation. In Zone 2, two males were on rocks and three on vegetation, one female on rock and one on vegetation. Pooling the results from both Zones, we found no differences in the substrate use between the sexes (Fisher exact test: $p=0.306$; $\mathrm{n}=19$ females and 29 males).

Out of the 48 animals observed foraging, 30 had their body parallel to the forest floor. Of these 30,23 had the ventral region facing the canopy and seven had the ventral region facing the floor. Eighteen animals had their body perpendicular to the forest floor, with 14 individuals facing the floor and four facing the canopy. Legs II were extended sideways with no contact with the substrate in 47 of the 48 animals.

\section{Oviposition sites}

Females of $H$. discolor oviposit mainly on substrates above the river (Fig. 2A and B), with 98 clutches found on granitic boulders and seven on a human made bridge. Among the boulders chosen for oviposition, 78 had moss, roots or small plants less than $3 \mathrm{~cm}$ from the eggs and 20 had no vegetation. Eighty five clutches were in non-exposed areas and 20 were in exposed areas. As for luminance, 46 clutches had values closer to 5 lux, 27 closer to 22 lux, 19 to 75 lux and 13 to 220 lux $(\mathrm{n}=105)$. The clutches were $132.32 \pm 110.38 \mathrm{~cm}$ (mean $\pm \mathrm{SD}$; $\mathrm{n}=105$ ) far from the water. In some cases the clutches were close enough that water would regularly spill on the eggs. All the 200 females were in resting posture (Fig. 3: body close to the substrate and legs flexed close to the body). Groups of clutches were often found: 80 clutches were less than a meter close to another clutch. We found 27 major and 20 minor males less than $1 \mathrm{~m}$ to a clutch $(\mathrm{n}=47$; only males that were less than a meter from the batches were counted). The mean number of eggs was $99(\mathrm{SD}=33$; $\min =4 ; \operatorname{Max}=150 ; \mathrm{n}=105)$. Twelve out of 210 clutches observed were infected with fungi, with a mean of $7.3 \%$ of the eggs infected $(\mathrm{SD}=9.1 ; \min =7.5$; $\max =26.4 \% ; n=8$, the remaining four could not be counted).

\section{Opportunistic observations}

We observed $H$. discolor females $(\mathrm{n}=5)$, ants (one observation, 13 ants: Myrmicinae, possibly Crematogaster sp.) and a reduviid heteropteran $(\mathrm{n}=1$, Zelurus sp., probably Z. travassosi, Fig. 4) feeding on unprotected eggs. We observed five egg-guarding females behaving aggressively towards conspecific females and two egg-guarding females mating with major males. We observed two males face-to-face fighting each other and after some seconds both fell in the river. A male was observed eating a cockroach and it is unknown if it was captured alive.

\section{Discussion}

Males and females were found foraging at similar distances from the river and the forest floor, which is consistent with the idea that they feed on similar food items. Both sexes were found more often in Zone 1, which may be related to the higher humidity in this area that is closer to the river (Machado et al. 2000; Santos 2007). Because the individuals rest on boulders that lay on rivers during the day, the fact that they were found more often in Zone 1 may also due to the fact that the individuals do not move a lot from their resting to foraging places.

No individual was seen foraging on leaf litter, unlike several harvestmen (Curtis \& Machado 2007) but similar to other species in the subfamily Goniosomatinae (Machado et al. 2000; Willemart \& Gnaspini 2004b; Caetano \& Machado 2013), which may climb higher than $20 \mathrm{~m}$ to forage (Santos \& Gnaspini 2002). The foraging site - vegetation, is clearly different from the resting and ovipositing sites - granitic

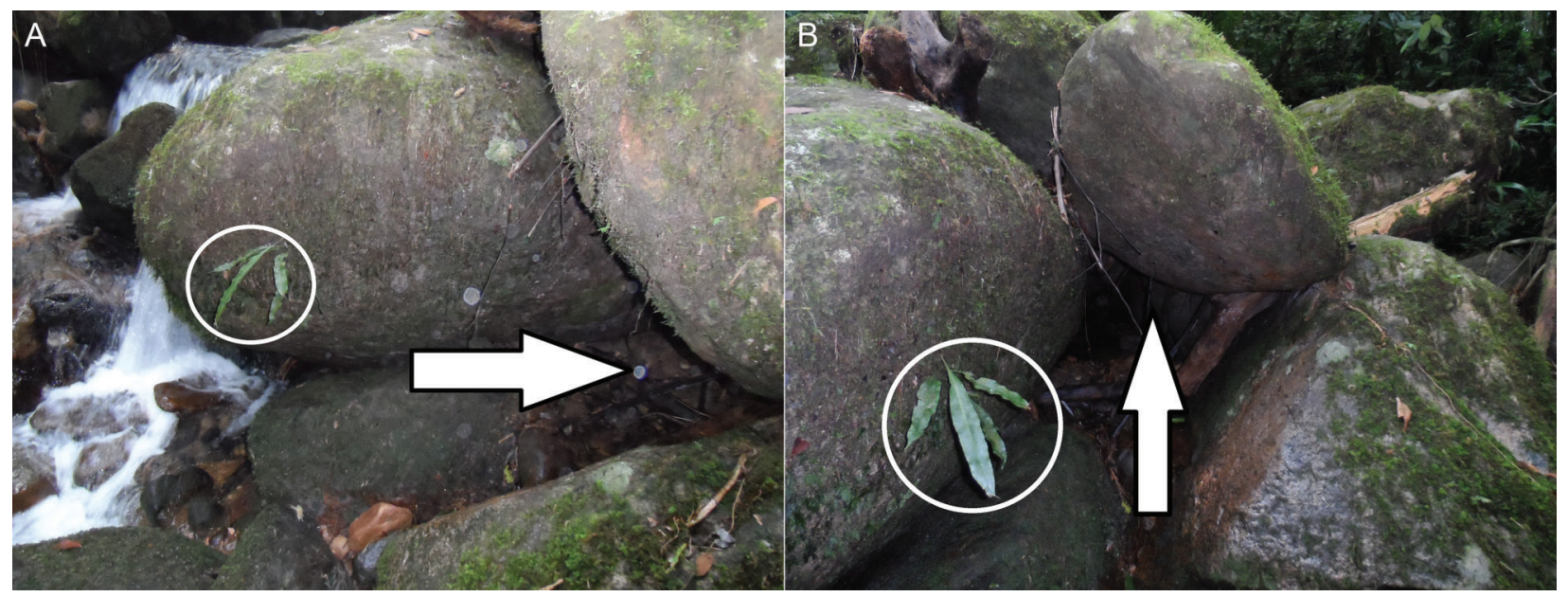

Figure 2 A and B. A typical shelter where the harvestman Heteromitobates discolor is found during the day. The same area is shown from different angles, with arrows showing the approximate region of an oviposition site. The circle indicates the same landmark in the two pictures. 


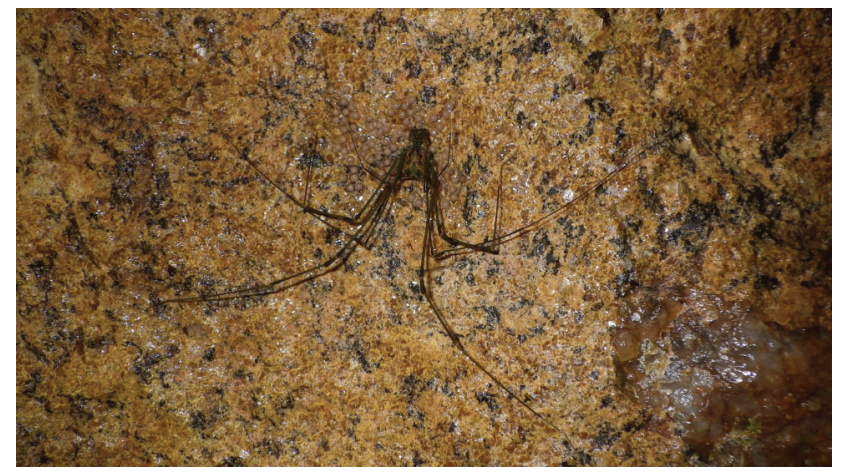

Figure 3. A female Heteromitobates discolor (body size $\sim 7 \mathrm{~mm}$ ) guarding eggs.

boulders. The latter are probably more humid because they are by the river and also probably less visited by predators than the vegetation. Although larger trechaleid spiders are also found on such boulders, harvestmen might be chemically and mechanically protected from their attacks (Machado et al. 2005; Souza \& Willemart 2011; Dias \& Willemart 2013; Segovia et al. 2015a, b). It is still not clear why some harvestmen forage on the vegetation and others on the floor. Although there seem to be a relation between leg length and resting area (leaf litter vs vegetation), with long-legged species being found on the vegetation and short-legged ones on the floor, leg length per se may not be an explanation for the foraging sites since several long-legged species in the suborder Eupnoi forage on the floor (Curtis \& Machado 2007; Donaldson \& Grether 2007).

All the individuals found at night were in a typical active posture in the subfamily Goniosomatinae, with the body away from the substrate and legs II extended sideways (Machado et al. 2000; Santos \& Gnaspini 2002; Willemart \& Gnaspini 2004b). Extending the legs probably increases the chances of detecting food mechanically by contact or chemically (Willemart et al. 2009; Willemart \& Chelini 2007; Costa \& Willemart 2013).

Egg batches were laid mainly in non-exposed and dark areas, contrasting with Heteromitobates albiscriptus



Figure 4. A heteropteran, Zelurus sp. (probably travassosi), on an egg batch of Heteromitobates discolor. Egg diameter $\sim 1.9 \mathrm{~mm}$.
(Gonyleptidae) (Willemart \& Gnaspini 2004a) that often lay eggs in exposed areas but similarly to two other species in other genera within Goniosomatinae (Gnaspini 1995; Machado \& Oliveira 1998), where eggs are laid by rivers or other sources of humidity. The number of eggs was similar to other species in Goniosomatinae (see Machado 2002). Almost 80\% of the clutches on boulders were within or less than $3 \mathrm{~cm}$ close to wet vegetation, which could be either to camouflage, to provide humidity for the eggs or even water for the females during the long period of egg guarding. Females may stay for more than a month and sometimes up to two months without leaving the clutch in closely related species (Gnaspini 1995; Machado \& Oliveira 1998; Willemart \& Gnaspini 2004a; Buzatto et al. 2007).

Active major males near egg guarding females during the day in this nocturnal species suggest male patrolling females as observed in other species of the subfamily (Machado \& Oliveira 1998; Buzatto \& Machado 2009). It is worth mentioning that only major males (no minor males) were observed within $10 \mathrm{~cm}$ of egg guarding females or mating with the egg guarding females. Females of Goniosomatinae do not remove fungi from the eggs and this represent a cost of laying eggs in such humid environments (Machado \& Oliveira 1998).

The predators of eggs observed in this study are common predators of eggs in large laniatorids of the Atlantic forest (Gnaspini 1996; Machado \& Oliveira 1998; Buzatto et al. 2007; Chelini \& Machado 2012). We added two taxa to the list of egg-predators for $H$. discolor provided in Machado (2002), namely ants (Myrmicinae, probably Crematogaster) and the reduviid (Zelurus sp.). Just as has been observed in other Goniosomatinae (e.g. Willemart \& Gnaspini, 2004b), females actively repel potential predators approaching their batches.

We have provided additional field data on a Goniosomatinae, complementing previous behavioral studies on closely related species. Our results matched what was considered to be typical of Goniosomatinae in Caetano \& Machado (2013) considering foraging and oviposition sites and presence of maternal care. Nocturnal observations on the foraging behavior in harvestmen are particularly scarce in the literature, with few data on the foraging sites and foraging posture. There are 30-40 species described in the subfamily (DaSilva \& Gnaspini 2009), of which 4 have been studied in details and 7 have been the target of some field observations (e.g. Gnaspini 1996; Machado 2002; Willemart \& Gnaspini 2004a; Buzatto \& Machado 2014). So far, following what we have discussed above, the behaviors reported here are similar to what is commonly observed in different genera of the subfamily, but more species should be studied to test this apparent high conservatism in Goniosomatinae.

\section{References}

ACOSTA, L.E. \& MACHADO, G. 2007. Diet and foraging. In Harvestmen: The Biology of Opiliones. (R. Pinto-da-Rocha, G. Machado \& G. Gibiret, eds.). Harvard University Press, Cambridge, Massachusetts, p.309-338.

BUZATTO, B.A. \& MACHADO, G. 2009. Amphisexual care in Acutisoma proximum (Arachnida, Opiliones), a neotropical harvestman with exclusive maternal care. Insectes Soc. 56:106-108, http://dx.doi.org/10.1007/s00040-008-1044-z

BUZATTO, B.A., REQUENA, G.S., LOURENÇO, R.S., MUNGUÍA-STEYER, R. \& MACHADO, G. 2011. Conditional male dimorphism and alternative reproductive tactics in a 
Neotropical arachnid (Opiliones). Evol. Ecol. 25:331-349, http://dx. doi.org/10.1007/s10682-010-9431-0

BUZATTO, B.A., REQUENA, G.S., MARTINS, E.G. \& MACHADO, G. 2007. Effects of maternal care on the lifetime reproductive success of females in a Neotropical harvestman. J. Anim. Ecol. 76:937-945, http://dx.doi.org/10.1111/jae.2007.76.issue-5

BUZATTO, B.A. \& MACHADO, G. 2014. Male dimorphism and alternative reproductive tactics in harvestmen (Arachnida: Opiliones). Behav. Process. 109:2-13, http://dx.doi.org/10.1016/j. beproc.2014.06.008

BUZATTO, B.A., TOMKINS, J.L., SIMMONS, L.W. \& MACHADO, G. 2014. Correlated evolution of sexual dimorphism and male dimorphism in a clade of Neotropical harvestmen. Evolution 68:1671-1686.

CAETANO, D.S. \& MACHADO, G. 2013. The ecological tale of Gonyleptidae (Arachnida, Opiliones) evolution: phylogeny of a Neotropical lineage of armoured harvestmen using ecological, behavioural and chemical character. Cladistics 29:589-609.

CHELINI, M.C. \& MACHADO, G. 2012. Costs and benefits of temporary brood desertion in a Neotropical harvestman (Arachnida: Opiliones). Behav. Ecol. Sociobiol. 66:1619-1627, http://dx.doi.org/10.1007/s00265-012-1417-1

COSTA, T.M. \& WILLEMART, R.H. 2013. First experimental evidence that a harvestman (Arachnida: Opiliones) detects odors of non-rotten dead prey by olfaction. Zoologia 30:359-361.

CURTIS, D.J. \& MACHADO, G. 2007. Ecology. In Harvestmen: The Biology of Opiliones. (R. Pinto-da-Rocha, G. Machado \& G. Giribet, eds.). Harvard University Press, Cambridge, Massachusetts, p.280-308.

DASILVA, M.B. \& GNASPINI, P. 2009. A systematic revision of Goniosomatinae (Arachnida: Opiliones: Gonyleptidae), with a cladistic analysis and biogeographical notes. Invertebr. Syst. 23:530-624, http://dx.doi.org/10.1071/IS09022

DIAS, B.C. \& WILLEMART, R.H. 2013. The effectiveness of post-contact defenses in a prey with no pre-contact detection. Zoology 116:168-174.

DONALDSON, Z.R. \& GRETHER, G.F. 2007. Tradition without social learning: scentmark-based communal roost formation in a Neotropical harvestman (Prionostemma sp.). Behav. Ecol. Sociobiol. 61:801-809, http://dx.doi.org/10.1007/s00265-006-0311-0

GNASPINI, P. 1995. Reproduction and postembryonic development of Goniosoma spelaeum, a cavernicolous harvestman from southeastern Brazil (Arachnida: Opiliones: Gonyleptidae). Invert. Reprod. \& Dev. 28:137-151.

GNASPINI, P. 1996. Population ecology of Goniosoma spelaeum, a cavernicolous harvestman from south-eastern Brazil (Arachnida: Opiliones: Gonyleptidae). J. Zool. 239:417-435, http://dx.doi.org/ 10.1111/jzo.1996.239.issue-3

MACHADO, G. 2002. Maternal care, defensive behavior, and sociality in Neotropical Goniosoma harvestmen (Arachnida, Opiliones). Insectes Soc. 49:388-393, http://dx.doi.org/10.1007/PL00012663

MACHADO, G., CARRERA, P.C., POMINI, A.M. \& MARSAIOLI, A.J. 2005. Chemical defense in harvestmen (Arachnida: Opiliones): do benzoquinones deter invertebrate and vertebrate predators? J. Chem. Ecol. 31:2519-2539, http://dx.doi.org/10.1007/s10886005-7611-0

MACHADO, G. \& MACÍAS-ORDÓÑEZ, R. 2007. Reproduction. In Harvestmen: The Biology of Opiliones. (R. Pinto-da-Rocha, G. Machado \& G. Giribet, eds.). Harvard University Press, Cambridge, Massachusetts, p.414-454.

MACHADO, G. \& OLIVEIRA, P.S. 1998. Reproductive biology of the neotropical harvestman (Goniosoma longipes) (Arachnida, Opiliones: Gonyleptidae): mating and oviposition behavior, brood mortality, and parental care. J. Zool. 246:359-367, http://dx.doi. org/10.1111/jzo.1998.246.issue-3

MACHADO, G., RAIMUNDO, R.L.G. \& OLIVEIRA, P.S. 2000. Daily activity schedule, gregariousness, and defensive behaviour in the Neotropical harvestman Goniosoma Gonyleptidae). J. Nat. Hist. 34:587-596, http://dx.doi.org/10.1080/002229300299453

SANTOS, F.H. 2007. Ecology. In Harvestmen: The Biology of Opiliones. (R. Pinto-da-Rocha, G. Machado \& G. Giribet, eds.). Harvard University Press, Cambridge, Massachusetts, p.473-488.

SANTOS, F.H. \& GNASPINI, P. 2002. Notes on the foraging behavior of the Brazilian cave harvestman Goniosoma spelaeum (Opiliones, Gonyleptidae). J. Arachnol. 30:177-180, http://dx.doi. org/10.1636/0161-8202(2002)030[0177:NOTFBO]2.0.CO;2

SEGOVIA, J.M.G., DEL-CLARO, K. \& WILLEMART, R.H. 2015. Defences of a Neotropical harvestman against different levels of threat by the recluse spider. Behaviour 152: 757-773.

SEGOVIA, J.M.G., DEL-CLARO, K. \& WILLEMART, R.H. 2015. Delicate fangs, smart killing: the predation strategy of the recluse spider. Anim. Behav. 101:169-177, http://dx.doi.org/10.1016/j.anbehav. 2014.12.025

SOUZA, E.D.S. \& WILLEMART, R.H. 2011. Harvest-ironman: heavy armature, and not its defensive secretions, protects a harvestman against a spider. Anim. Behav. 81:127-133, http://dx. doi.org/10.1016/j.anbehav.2010.09.023

WILLEMART, R.H. \& CHELINI, M.C. 2007. Experimental demonstration of close-range olfaction and contact chemoreception in the Brazilian harvestman Iporangaia pustulosa. Entomol. Exp. Appl. 123:73-79, http://dx.doi.org/10.1111/eea.2007.123.issue-1

WILLEMART, R.H., FARINE, J.P. \& GNASPINI, P. 2009. Sensory biology of Phalangida harvestmen (Arachnida, Opiliones): a review, with new morphological data on 18 species. Acta Zool. 90:209-227, http://dx.doi.org/10.1111/azo.2009.90.issue-3

WILLEMART, R. H. \& GNASPINI, P. 2004a. Breeding Biology of the cavernicolous harvestman Goniosoma albiscriptum (Arachnida, Opiliones, Laniatores): sites of oviposition, egg batches characteristics and subsocial behavior. Invert. Rep. Dev. 45:15-28, http://dx.doi.org/10.1080/07924259.2004.9652570

WILLEMART, R. H. \& GNASPINI, P. 2004b. Spatial distribution, mobility, gregariousness, and defensive behavior in a Brazilian cave harvestman Goniosoma albiscriptum (Arachnida, Opiliones, Gonyleptidae). Anim. Biol. 54:221-235, http://dx.doi.org/10.1163/ 1570756042484674 